\title{
Expression and validation of PvPGIP genes for resistance to white mold (Sclerotinia sclerotiorum) in common beans (Phaseolus vulgaris L.)
}

\author{
R.C.C. Vasconcellos, T.F.C. Lima, C.N. Fernandes-Brum, \\ A. Chalfun-Junior and J.B. Santos \\ Departamento de Biologia, Universidade Federal de Lavras, Lavras, MG, Brasil \\ Corresponding author: R.C.C. Vasconcellos \\ E-mail: renatoccv@hotmail.com \\ Genet. Mol. Res. 15 (3): gmr.15038269 \\ Received December 14, 2015 \\ Accepted April 8, 2016 \\ Published August 18, 2016 \\ DOI http://dx.doi.org/10.4238/gmr.15038269
}

Copyright $(2016$ The Authors. This is an open-access article distributed under the terms of the Creative Commons Attribution ShareAlike (CC BY-SA) 4.0 License

\begin{abstract}
The interaction between polygalacturonase-inhibiting proteins (PGIPs), produced by plants, and endopolygalacturonases (PGs), produced by fungi, limits the destructive potential of PGs and can trigger plant defense responses. This study aimed to i) investigate variation in the expression of different common bean (Phaseolus vulgaris L.) genotypes and its relationship with resistance to white mold (Sclerotinia sclerotiorum); ii) determine the expression levels of $P v P G I P$ genes at different time points after inoculation with white mold; and iii) investigate differences in $P v P G I P$ gene expression between two white mold isolates with different levels of aggressiveness. Four bean lines were analyzed, including two lines from a recurrent selection for white mold (50/5 and 84/6), one resistant line that was not adapted to Brazilian conditions (Cornell 605), and one susceptible line
\end{abstract}


(Corujinha). Gene expression was investigated at $0,1,2,3$, and 5 days after inoculation. The isolate UFLA 03 caused no significant difference in the relative expression of any gene examined, and was inefficient in discriminating among the genotypes. For the isolate UFLA 116, all of the genes were differentially expressed, as they were associated with resistance to white mold, and the expressions increased until the third day after inoculation. The 50/5 line was not significantly different from the Corujinha line for all of the genes analyzed. However, this line had a resistance level that was similar to that of Cornell 605, according to the straw test. Therefore, the incorporation of $P v P G I P$ genes can increase the resistance of lines derived from recurrent selection.

Key words: Sclerotinia sclerotiorum; Polygalacturonase-inhibiting protein; Endopolygalacturonase; qPCR

\section{INTRODUCTION}

The common bean (Phaseolus vulgaris L.) is significantly affected by pathogens that can cause a considerable loss in yield, and should therefore not be planted in certain regions and at particular periods of the year. White mold (Sclerotinia sclerotiorum (Lib.) De Bary) is one of the most important diseases that limit high bean yield.

Under favorable conditions, white mold can cause losses of up to $100 \%$ in the production of bean cultivars susceptible to the fungus. White mold occurs in South and North American countries, mainly the United States, Canada, Argentina, and Brazil (Schwartz and Singh, 2013). Currently, it is the most destructive disease in irrigated areas of Brazil, particularly in crops planted in the fall, winter, or spring because the temperatures are lower, consequently increasing the growth and spread of the fungus.

The integrated use of strategies to stop the advance of white mold in bean crops must combine various techniques, such as the use of fungicides, low plant density, the reduced use of irrigation and fertilizers, and the use of erect cultivars with an open canopy. These measures are useful in controlling the disease, but can also cause a reduction in yield and increase production costs, so the use of cultivars with partial resistance to the fungus, good cultivation practices and the use of fungicides have been considered the most suitable for controlling and reducing the impact of the disease (Schwartz and Singh, 2013).

The strategy of using resistant cultivars is difficult to implement, mainly due to a lack of sources of resistance, partial resistance has moderate to low heritability, inaccuracy in the assessment of the disease, and the difficulty of introgressing quantitative trait loci (QTL) into adapted cultivars (Miklas, 2007). Most known sources of resistance to white mold are of Andean origin, or from a secondary gene pool, such as P. coccineus L. (Singh et al., 2009). It is important to identify sources of resistance in the Mesoamerican gene pool that are adapted to crop conditions in Brazilian soils and are commercially acceptable.

Because high resistance is only found in non-adapted sources and adapted lines have relatively low resistance levels, the transfer of resistance QTLs is of great importance. Given the complexity of the trait, the most efficient method of obtaining resistant and adapted plants is through recurrent selection, as it allows the use of various sources of resistance as parents and allows the gradual transfer of favorable alleles to their progeny over successive selection cycles.

Genetics and Molecular Research 15 (3): gmr.15038269 
Resistance to white mold involves mechanisms that are related to physiological resistance and escape. Among the genes that are involved in physiological resistance, specific ones have a large effect and general ones minimize the damage caused by the pathogen, and/or impede the pathogen's progress in plant tissues (Leite et al., 2014). The latter include a gene family that synthesizes polygalacturonase-inhibiting proteins (PGIPs).

White mold produces a large number of molecules during the infection and colonization of plant tissues to overcome barriers such as cell walls. Among these molecules, enzymes that degrade the cell wall (cell wall-degrading enzymes, CWDEs) represent an important pathogenicity factor, and endopolygalacturonases (PGs) are one of the first CWDEs released during the infection process (Kalunke et al., 2011). Host plants produce PGIPs that recognize PGs, and prevent enzymatic action during invasion and the release of nutrients required for the growth of the pathogen (D'Ovidio et al., 2004a). Besides the inhibition of PGs, the interaction between PGs and PGIPs promotes the formation of oligogalacturonides, which are elicitors of a variety of defense responses (Cervone et al., 1989; Ridley et al., 2001; Ferrari et al., 2013).

PGIPs are cell wall glycoproteins that belong to the extracytoplasmic LRR (leucinerich repeat proteins) superfamily (Jones and Jones, 1997). Genes that encode these proteins have been characterized in both monocotyledons and dicotyledons. Genomic analyses have shown that PGIP genes may exist as a single gene, for example in diploid wheat species (Di Giovanni et al., 2008), or are organized into gene families whose members are tandemarranged and may vary from two, as in Arabidopsis thaliana (Ferrari et al., 2003), to 16, as in Brassica napus (Hegedus et al., 2008). The overexpression of PGIP genes in transgenic plants such as wheat, tomato, tobacco, and A. thaliana limits fungal colonization (Powell et al., 2000; Ferrari et al., 2003; Manfredini et al., 2005; Janni et al., 2008).

In beans, this gene family consists of four genes in a cluster (PvPGIP1, PvPGIP2, $P v P G I P 3$, and $P v P G I P 4)$ that covers a 50-kb region in linkage group Pv02, which have a nucleotide sequence similarity greater than $80 \%$. In the soybean (Glycine max), GmPGIP3, which is the most highly expressed gene of this family in the species, is phylogenetically grouped with $P v P G I P 1$ and $P v P G I P 2$, suggesting that the duplication that originated the ancestors of $P v P G I P 1 / P v P G I P 2$ and PvPGIP3/PvPGIP4 occurred before the separation of Glycine and Phaseolus (Kalunke et al., 2014). Among these genes, $P v P G I P 2$ is the most efficient in inhibiting the largest number of fungal PGs (Manfredini et al., 2005; D’Ovidio et al., 2004b, 2006). In addition, the highly conserved nature of the nucleotide sequence of this gene in various lines and species of Phaseolus indicates high adaptive significance (Farina et al., 2009).

Because of the important role that the PGIP gene family plays in limiting fungal colonization in plant tissues, and the consequent positive impact on bean yield and quality, the goals of this study were: i) to investigate variation in the expression of different Andeanand Mesoamerican-source genotypes and its relationship with white mold resistance; ii) to determine the expression levels of $P v P G I P$ genes at different days after inoculation with white mold; and iii) to investigate differences in $P v P G I P$ gene expression between two white mold isolates with different levels of aggressiveness.

\section{MATERIAL AND METHODS}

Four bean lines were used, including two resistant lines derived from a recurrent selection for white mold with a Carioca grain type of Mesoamerican origin and adapted

Genetics and Molecular Research 15 (3): gmr.15038269 
to growing conditions in southeastern Brazil (Leite et al., 2016), one non-adapted source of resistance (Cornell 605; Griffiths, 2009), and one susceptible to white mold as a control (Corujinha; Silva et al., 2014).

Two S. sclerotiorum isolates were used: UFLA 116, a highly aggressive isolate from Ijaci County, Minas Gerais, Brazil, and UFLA 03, a less aggressive isolate from Lambari, Minas Gerais, Brazil (Leite et al., 2016). Both isolates were obtained from the mycology collection of the Laboratory of Plant Disease Resistance, Biology Department, Federal University of Lavras, Brazil.

The sclerotia were superficially disinfected by consecutive immersion in $70 \%$ ethanol for $1 \mathrm{~min}$ and 20\% sodium hypochlorite for $3 \mathrm{~min}$, and washed three times in demineralized and sterile water. Subsequently, the fungus was grown on Petri dishes containing potato dextrose agar (PDA). Chloramphenicol was added to the PDA medium $(100 \mu \mathrm{L}$ chloramphenicol to 100 $\mathrm{mL}$ medium) and maintained in growth B.O.D (Biological Oxygen Demand)-type chamber at $22^{\circ} \mathrm{C}$ for 3 days. The inoculum was grown again to obtain greater uniformity under the same conditions. Petri dishes that were completely covered with mycelium were used for the preparation of $200-\mu \mathrm{L}$ micropipette tips for subsequent inoculation.

The experiment was conducted with a completely randomized design with three replications. Seeds of each line were sown in pots containing $3.5 \mathrm{~L}$ sterile substrate, kept in a greenhouse, and regularly watered and fertilized according to the recommendations for the crop. Inoculation of the fungus was performed using the straw test method described by Terán et al. (2006) 30 days after seedling emergence. Two stems per plant were inoculated.

Samples were collected $24,48,72$, and $120 \mathrm{~h}$ after inoculation $(1,2,3$, and 5 days after inoculation, DAI) by cutting the stem $2.5 \mathrm{~cm}$ from the inoculation point, and collected tissues contained both infected and healthy regions. Agar discs without mycelium were inserted in the control plants (0 DAI), and samples were collected $24 \mathrm{~h}$ later. Samples were placed in 2.0-mL microcentrifuge tubes, immersed in liquid nitrogen, and stored in a freezer at $-80^{\circ} \mathrm{C}$ until RNA extraction. Mean values of disease severity (Terán et al., 2006) for each time point and isolate inoculated in each line were subjected to analysis of variance.

Concert ${ }^{\mathrm{TM}}$ Plant RNA Reagent (Invitrogen) was used to extract total RNA following the manufacturer recommendations, with modifications. The samples were washed twice with $\mathrm{NaCl}$ and chloroform in order to increase the quality of the RNA, and were subsequently treated with DNase using a Turbo DNA-free ${ }^{\mathrm{TM}}$ kit (Ambion) to eliminate DNA residues. RNA integrity was checked on a $1 \%$ agarose gel and the samples were quantified using NanoVue v2.0.4 4282. Samples with high integrity and purity were used for cDNA synthesis using a High-Capacity cDNA Reverse Transcription Kit (Applied Biosystems). After cDNA synthesis, the samples were stored at $-20^{\circ} \mathrm{C}$.

The primers used were as follows: $P v P G I P 1$ (F: 5'-CGCCTCACCGGGAAGAT-3'; R: 5'-TGTTCCGAGACAAGTCAACGAA-3'), $P v P G I P 2$ (F: 5'-TTCGACGGCAACCGAATC -3'; R: 5'-TGGTCATCGACGTAAACAGCTT-3'), $P v P G I P 3$ (F: 5'-TCCTTCCCGAAGCATT TCAC-3'; R: 5'-GCGTCGCCGGTATATTGC-3'), and PvPGIP4 (F: 5'-TCCTTCCCGAAGC ATTTCAC-3'; R: 5'-GCCAGCGTCGTCGGAATAT-3'). The fragment sizes were 70, 76, 84, and 106 , respectively.

Gene expression was analyzed by quantitative polymerase chain reaction (qPCR) with reactions containing $40 \mathrm{ng} \mathrm{cDNA}, 1.5 \mathrm{mM}$ each primer, $7.5 \mu \mathrm{L}$ SYBR $^{\circledR}$ Green UDG Master Mix with ROX (Invitrogen), and $3 \mu \mathrm{L}$ autoclaved and double-distilled water, which

Genetics and Molecular Research 15 (3): gmr.15038269 
yielded a final volume of $13.5 \mu \mathrm{L}$ per sample; technical triplicates were performed for each sample. The qPCR cycling conditions were as follows: 2 min at $50^{\circ} \mathrm{C}, 10 \mathrm{~min}$ at $95^{\circ} \mathrm{C}$, followed by 40 cycles of $15 \mathrm{~s}$ at $95^{\circ} \mathrm{C}$ and $1 \mathrm{~min}$ at $60^{\circ} \mathrm{C}$ using a Rotor-Gene Kit (Qiagen). The data were confirmed with a melting curve using the Rotor-Gene q Series Software (v.2.1.0). Relative expression was calculated using the $2^{-\Delta \Delta \mathrm{Ct}}$ method (Pfaffl, 2001), with $\alpha$-actin (F: 5'-TGCATACGTTGGTGATGAGG-3'; R: 5'-AGCCTTGGGGTTAAGAGGAG-3') and insulin-degrading enzyme (F: 5'-GCAACCAACCTTTCATCAGC-3'; R: 5'-AGAAATGCCTCAACCCTTTG-3') as reference genes.

\section{RESULTS}

The experiment was conducted with high selective accuracy $(r g \hat{g}=0.95)$. There were significant differences between lines, isolates, and time points, and the interaction between isolate and time, in white mold severity $(\mathrm{P} \leq 0.01)$ (Table 1). These differences were expected, because both susceptible and resistant lines were included in the experiment, as well as highly aggressive and less aggressive isolates. The isolate $\mathrm{x}$ time interaction was significant because of the difference in disease severity between the lines inoculated with a highly aggressive isolate (UFLA 116) and those inoculated with a less aggressive isolate (UFLA 03).

There were no significant interactions between line and time, line and isolate, and line and isolate and time. This indicates that the responses of the lines and isolates were consistent over time, i.e., lines that were more resistant and isolates that were less aggressive exhibited lower severity scores over time.

Table 1. Analysis of variance results (F-test) for severity of white mold.

\begin{tabular}{l|c|c}
\hline Source of variation & d.f. & Mean squares \\
\hline Isolate & 1 & $18.3750^{* *}$ \\
\hline Replication & 2 & $0.1250^{\mathrm{NS}}$ \\
\hline Line & 3 & $2.9167^{* *}$ \\
\hline Time & 3 & $37.6944^{* *}$ \\
\hline Line $x$ Time & 9 & $0.3333^{\mathrm{NS}}$ \\
\hline Line $\mathrm{x}$ Isolate & 3 & $0.0694^{\mathrm{NS}}$ \\
\hline Isolate $\mathrm{x}$ Time & 3 & $2.0694^{* *}$ \\
\hline Line $\mathrm{x}$ Isolate $\mathrm{x}$ Time & 9 & $0.0972^{\mathrm{NS}}$ \\
\hline Error & 62 & 0.2862 \\
\hline
\end{tabular}

**Significant at the $1 \%$ probability level; NS, not significant.

UFLA 03 inoculation resulted in low relative expression levels of all of the PvPGIP genes in all of the genotypes and at all time points, without any significant difference according to the Scott-Knott test at the 5\% probability level between treatments, and was therefore inefficient in discriminating between bean genotypes for this gene family. However, UFLA 116 was able to distinguish between at least one treatment for each gene, indicating that all of the $P v P G I P$ genes were differentially expressed and were associated with resistance to white mold, and increased until the third day after inoculation. Cornell 605 exhibited significantly higher PvPGIP1 expression levels at 3 DAI with UFLA 116 than the other lines; there were no other significant differences between the lines (Figure 1).

Genetics and Molecular Research 15 (3): gmr.15038269 


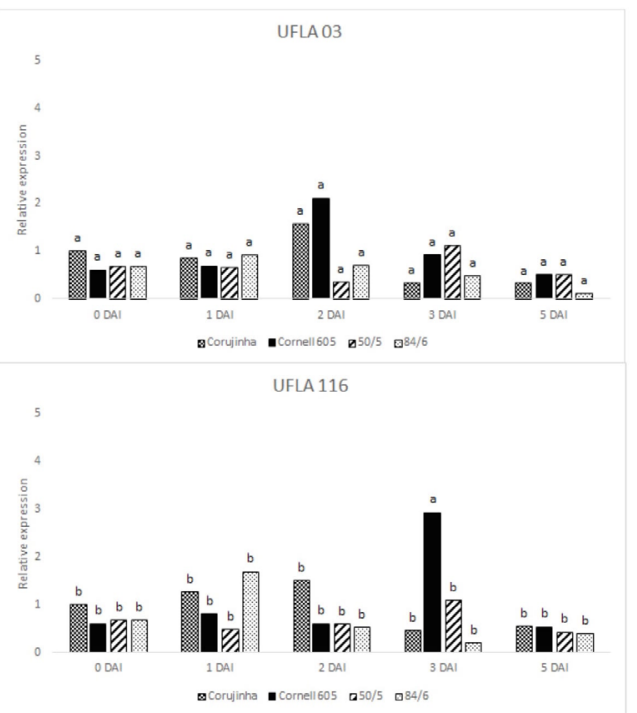

Figure 1. Relative expression levels of PvPGIP1 in Corujinha, Cornell 605, 50/5, and 84/6 bean lines at 0, 1, 2, 3 , and 5 days after inoculation (DAI) with UFLA 03 and UFLA 116 isolates of Sclerotinia sclerotiorum. Bean lines with different letters were significantly different at the $5 \%$ probability level according to the Scott-Knott test.

Cornell 605 also exhibited significantly higher PvPGIP2 expression levels at 3 DAI with UFLA 116 than the other lines, with a relative expression level that was approximately 19-fold greater than that of the Corujinha line, which was the largest difference observed for all of the genes. The 84/6 line exhibited significantly higher PvPGIP2 expression levels at 2 DAI with UFLA 116 than the other lines, but were lower than those observed in Cornell 605 at 3 DAI (Figure 2).

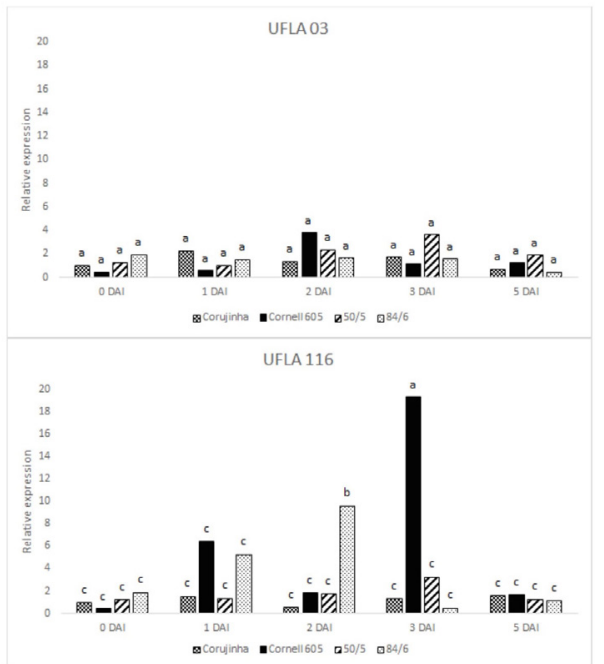

Figure 2. Relative expression levels of PvPGIP2 in Corujinha, Cornell 605, 50/5, and 84/6 bean lines at 0, 1, 2, 3 , and 5 days after inoculation (DAI) with UFLA 03 and UFLA 116 isolates of Sclerotinia sclerotiorum. Bean lines with different letters were significantly different at the $5 \%$ probability level according to the Scott-Knott test. 
Cornell 605 exhibited significantly higher PvPGIP3 expression levels at 3 DAI with UFLA 116 than the other lines, indicating that there was a peak in $P v P G I P 1, P v P G I P 2$, and $P v P G I P 3$ expression at $3 \mathrm{DAI}$ and that Cornell 605 was superior to the other lines. PvPGIP3 expression levels in Cornell 605 at 1 and 2 DAI, and in 84/6 at 1 and 3 DAI, were also significantly higher than in the other lines (Figure 3).

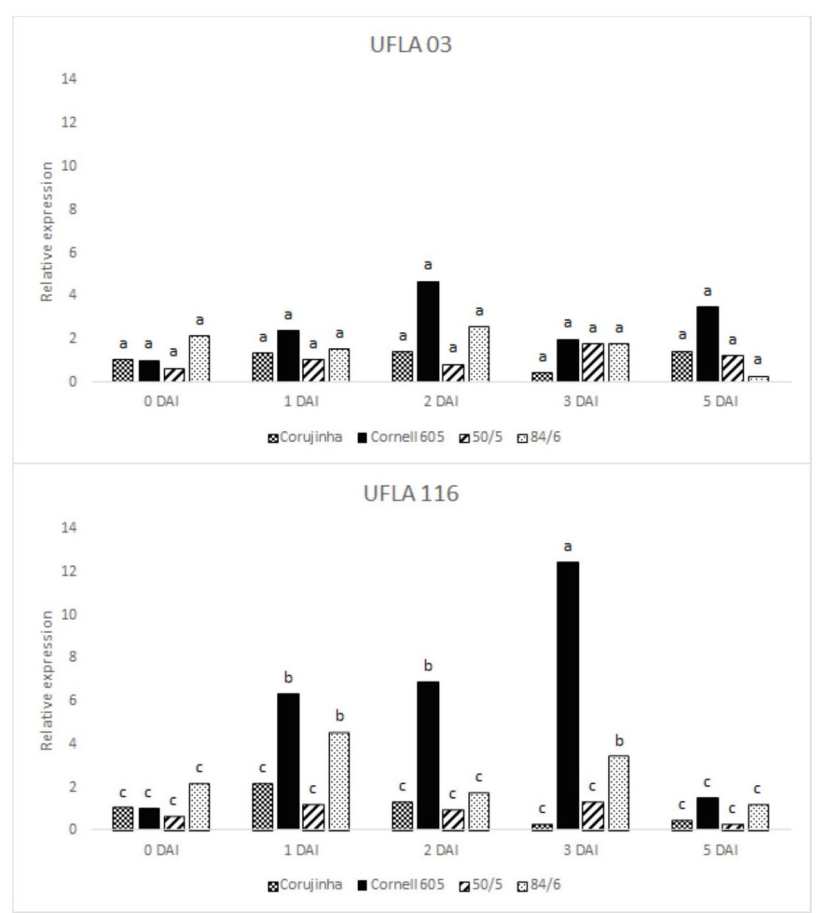

Figure 3. Relative expression levels of $P v P G I P 3$ in Corujinha, Cornell $605,50 / 5$, and $84 / 6$ bean lines at $0,1,2,3$, and 5 days after inoculation (DAI) with UFLA 03 and UFLA 116 isolates of Sclerotinia sclerotiorum. Bean lines with different letters were significantly different at the $5 \%$ probability level according to the Scott-Knott test.

PvPGIP4 was more highly expressed in Cornell 605 at 1, 2, and 3 DAI with UFLA 116 than the other lines, confirming the superiority of this line in expressing genes of the $P v P G I P$ family (Figure 4).

In all of the genotypes, there was a large reduction in relative gene expression at 5 DAI, with levels similar to those observed at 0 DAI, indicating that the genes of this family are only highly expressed during the early stages of disease development and plant defense.

For all of the genes analyzed, the 50/5 line was not significantly different from the susceptible line Corujinha, with low relative expression levels at all time points. The 50/5 line had an overall mean severity value of 2.70 and Corujinha had 3.08, which were not statistically different according to the Scott-Knott test at the 5\% probability level. The lowest overall mean was obtained by line 84/6 (2.33), which was not statistically different to the non-adapted source of resistance, Cornell 605 (2.37), which had the highest relative expression level of all of the genes of the family, indicating that $84 / 6$ may be considered a good source of resistance. 


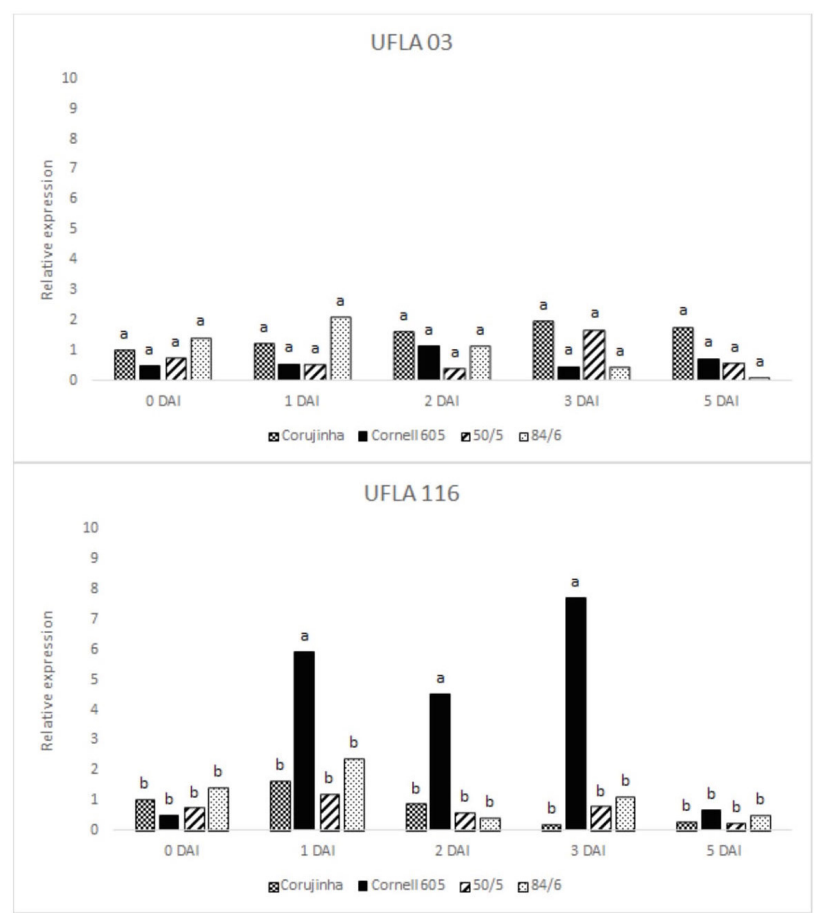

Figure 4. Relative expression levels of PvPGIP4 in Corujinha, Cornell 605, 50/5, and 84/6 bean lines at $0,1,2,3$, and 5 days after inoculation (DAI) with UFLA 03 and UFLA 116 isolates of Sclerotinia sclerotiorum. Bean lines with different letters were significantly different at the 5\% probability level according to the Scott-Knott test.

\section{DISCUSSION}

There is no full physiological resistance to white mold in beans, although some bean lines with partial resistance have been identified (Gonçalves and dos Santos, 2010). A few commercial lines have been developed by traditional breeding that have satisfactory partial resistance to white mold (Miklas, 2007). A high level of resistance has been reported in the secondary gene pool, such as in P. coccineus and some Andean lines of P. vulgaris (Myers et al., 2008).

Although four genes of the $P v P G I P$ family exhibited high genotype sequence similarity $(>80 \%)$, there was variation in the expression of these genes between the bean genotypes and days after inoculation, suggesting that each gene contributes differently and independently to plant defense. Indeed, there is evidence that these genes can differentially respond to elicitors such as salicylic acid and mechanical injury (D'Ovidio et al., 2004a). Therefore, at 0 DAI, they were probably already highly expressed, as they were collected $24 \mathrm{~h}$ after insertion of the agar disc, which caused mechanical damage in the collection region.

Differential expression of PGIP genes enables the plant to defend itself even under different environmental conditions, and against the attack of various types of PG produced by the pathogen. The effectiveness of PGIP genes in controlling diseases has been demonstrated in a wide variety of organisms, such as fungi, bacteria, and even insects (Kalunke et al., 2015).

Genetics and Molecular Research 15 (3): gmr.15038269 
PvPGIP2 is the most effective inhibitor of PGs (D'Ovidio et al., 2004a; Manfredini et al., 2005). This gene exhibited the highest relative expression level after inoculation in the present study. Oliveira et al. (2010) also reported high PvPGIP2 expression in the Pérola bean cultivar, but only at $2 \mathrm{DAI}$, and there was a decrease in its expression from 3 DAI. Transgenic plants that express PvPGIP2 exhibit a reduction of about $35 \%$ in symptoms caused by Botrytis cinerea (Manfredini et al., 2005), and they exhibit reduced symptoms of Rhizoctonia solani, Phytophthora parasitica var. nicotianae, and Peronospora hyoscyami f. sp tabacina attack (Borras-Hidalgo et al., 2012), suggesting that this gene plays a key role in plant innate immunity and contributes to basal resistance against different fungal species.

Tomato plants that express $P v P G I P 1$ do not exhibit any increase in resistance to Fusarium oxysporum f. sp lycopersici, B. cinerea, or Alternaria solani, possibly because of the inability of PvPGIPI to inhibit PGs that are secreted by these fungi (Desiderio et al., 1997).

Mkwaila et al. (2011) identified a QTL for the straw test method using a TW population (Tacana x PI318695) in the Pv02 linkage group near the BM143 marker. The authors suggest that this is the same QTL that was detected in Bunsi/Raven (Ender and Kelly, 2005) and G122/ CO72548 populations (Maxwell et al., 2007), and designated it WM2.3 $3^{\mathrm{BR}, \mathrm{GC}, \mathrm{TW}}$. According to Soule et al. (2011), this is the 10th QTL for disease resistance identified in this region, which also contains plant defense genes PGIP, chalcone synthase, and PvPR-2, which are proteins associated with plant defense responses, the genes of which are involved in plant defense against fungal pathogens, so they may be involved in host defense against $S$. sclerotiorum. Furthermore, QTLs for resistance to blight (Thanatephorus cucumeris) and common bacterial blight are found in the same region (Miklas et al., 2006).

Although the lines derived from recurrent selection (84/6 and 50/5) exhibit good resistance to white mold by the straw test method as observed in this study and by Leite et al. (2016), PvPGIP expression levels were still well below those demonstrated by Cornell 605 , suggesting that the incorporation of lines with high expression levels of these genes in breeding programs can further improve the resistance levels of lines. Moreover, these genes were only expressed during the first days after inoculation with white mold, and from the fifth day after inoculation, all of the genes exhibited similar relative expression levels.

In general, both in the greenhouse and in the field, breeders perform only one assessment for white mold at 7 DAI, but Viteri et al. (2015) conducted analyses at 7, 14, 21,28 , and 35 DAI, and showed that until 21 DAI there are differences in the resistance of lines, suggesting that in addition to these genes, which are expressed during the early stages of plant defense, there must be genes that are expressed later. In addition, the two resistant lines derived from recurrent selection exhibit similar levels of resistance to that of Cornell 605 (Leite et al., 2016), although they express $P v P G I P$ genes at a lower intensity. Therefore, other resistance mechanisms have been included in the phenotypic selection of these lines.

Although a high level of PvPGIP expression alone does not prevent white mold infection, it significantly limits the colonization of host tissue, and consequently improves grain yield and quality. Therefore, the cDNA sequences of these genes can be used for the development of molecular markers, which can subsequently be incorporated into recurrent selection programs for resistance to white mold.

\section{Conflicts of interest}

The authors declare no conflict of interest.

Genetics and Molecular Research 15 (3): gmr.15038269 


\section{ACKNOWLEDGMENTS}

Research supported by Conselho Nacional de Desenvolvimento Científico e Tecnológico (CNPq) and Fundação de Amparo à Pesquisa do Estado de Minas Gerais (FAPEMIG).

\section{REFERENCES}

Borras-Hidalgo O, Caprari C, Hernandez-Estevez I, Lorenzo GD, et al. (2012). A gene for plant protection: expression of a bean polygalacturonase inhibitor in tobacco confers a strong resistance against Rhizoctonia solani and two oomycetes. Front. Plant Sci. 3: 268. http://dx.doi.org/10.3389/fpls.2012.00268

Cervone F, Hahn MG, De Lorenzo G, Darvill A, et al. (1989). Host-pathogen interactions: XXXIII. A plant protein converts a fungal pathogenesis factor into an elicitor of plant defense responses. Plant Physiol. 90: 542-548. http:// dx.doi.org/10.1104/pp. 90.2 .542

Desiderio A, Aracri B, Leckie F, Mattei B, et al. (1997). Polygalacturonase-inhibiting proteins (PGIPs) with different specificities are expressed in Phaseolus vulgaris. Mol. Plant Microbe Interact. 10: 852-860. http://dx.doi.org/10.1094/ MPMI.1997.10.7.852

Di Giovanni M, Cenci A, Janni M and D’Ovidio R (2008). A LTR copia retrotransposon and Mutator transposons interrupt Pgip genes in cultivated and wild wheats. Theor. Appl. Genet. 116: 859-867. http://dx.doi.org/10.1007/s00122-008$\underline{0719-1}$

D’Ovidio R, Mattei B, Roberti S and Bellincampi D (2004a). Polygalacturonases, polygalacturonase-inhibiting proteins and pectic oligomers in plant-pathogen interactions. Biochim. Biophys. Acta 1696: 237-244. http://dx.doi.org/10.1016/j. bbapap.2003.08.012

D'Ovidio R, Raiola A, Capodicasa C, Devoto A, et al. (2004b). Characterization of the complex locus of bean encoding polygalacturonase-inhibiting proteins reveals subfunctionalization for defense against fungi and insects. Plant Physiol. 135: 2424-2435. http://dx.doi.org/10.1104/pp.104.044644

D’Ovidio R, Roberti S, Di Giovanni M, Capodicasa C, et al. (2006). The characterization of the soybean polygalacturonaseinhibiting proteins (Pgip) gene family reveals that a single member is responsible for the activity detected in soybean tissues. Planta 224: 633-645. http://dx.doi.org/10.1007/s00425-006-0235-y

Ender M and Kelly JD (2005). Identification of QTL associated with white mold resistance in common bean. Crop Sci. 45: 2482-2490. http://dx.doi.org/10.2135/cropsci2005.0064

Farina A, Rocchi V, Janni M, Benedettelli S, et al. (2009). The bean polygalacturonase-inhibiting protein 2 (PvPGIP2) is highly conserved in common bean (Phaseolus vulgaris L.) germplasm and related species. Theor. Appl. Genet. 118: 1371-1379. http://dx.doi.org/10.1007/s00122-009-0987-4

Ferrari S, Vairo D, Ausubel FM, Cervone F, et al. (2003). Tandemly duplicated Arabidopsis genes that encode polygalacturonase-inhibiting proteins are regulated coordinately by different signal transduction pathways in response to fungal infection. Plant Cell 15: 93-106. http://dx.doi.org/10.1105/tpc.005165

Ferrari S, Savatin DV, Sicilia F, Gramegna G, et al. (2013). Oligogalacturonides: plant damage-associated molecular patterns and regulators of growth and development. Front. Plant Sci. 4: 49. http://dx.doi.org/10.3389/fpls.2013.00049

Gonçalves PRC and dos Santos JB (2010). Physiological resistance of common bean cultivars and lines to white mold based on oxalic acid reaction. Annu. Rep. Bean Improv. Coop. 53: 236-237.

Griffiths PD (2009). Release of Cornell 601-606: common bean breeding lines with resistance to white mold. HortScience 44: 463-465.

Hegedus DD, Li R, Buchwaldt L, Parkin I, et al. (2008). Brassica napus possesses an expanded set of polygalacturonase inhibitor protein genes that are differentially regulated in response to Sclerotinia sclerotiorum infection, wounding and defense hormone treatment. Planta 228: 241-253. http://dx.doi.org/10.1007/s00425-008-0733-1

Janni M, Sella L, Favaron F, Blechl AE, et al. (2008). The expression of a bean PGIP in transgenic wheat confers increased resistance to the fungal pathogen Bipolaris sorokiniana. Mol. Plant Microbe Interact. 21: 171-177. http://dx.doi. org/10.1094/MPMI-21-2-0171

Jones DA and Jones JDG (1997). The role of leucine-rich repeat proteins in plant defenses. Adv. Bot. Res. 24: 89-167. http://dx.doi.org/10.1016/S0065-2296(08)60072-5

Kalunke RM, Janni M, Sella L, David P, et al. (2011). Transcript analysis of the bean polygalacturonase-inhibiting protein gene family reveals that Pvpgip 2 is expressed in the whole plant and is strongly induced by pathogen infection. $J$. Plant Pathol. 93: 141-148.

Genetics and Molecular Research 15 (3): gmr.15038269 
Kalunke RM, Cenci A, Volpi C, O'Sullivan DM, et al. (2014). The pgip family in soybean and three other legume species: evidence for a birth-and-death model of evolution. BMC Plant Biol. 14: 189. http://dx.doi.org/10.1186/s12870-014$\underline{0189-3}$

Kalunke RM, Tundo S, Benedetti M, Cervone F, et al. (2015). An update on polygalacturonase-inhibiting protein (PGIP), a leucine-rich repeat protein that protects crop plants against pathogens. Front. Plant Sci. 6: 146. http://dx.doi. org/10.3389/fpls.2015.00146

Leite ME, Santos JB, Ribeiro PM Junior, Souza DA, et al. (2014). Biochemical responses associated with common bean defense against Sclerotinia sclerotiorum. Eur. J. Plant Pathol. 138: 391-404. http://dx.doi.org/10.1007/s10658-013$\underline{0341-1}$

Leite ME, Dias JA, Souza DAD, Alves FC, et al. (2016). Increasing the resistance of common bean to white mold through recurrent selection. Sci. Agric. 73: 71-78. http://dx.doi.org/10.1590/0103-9016-2015-0084

Manfredini C, Sicilia F, Ferrari S, Pontiggia D, et al. (2005). Polygalacturonase-inhibiting protein 2 of Phaseolus vulgaris inhibits BcPG1, a polygalacturonase of Botrytis cinerea important for pathogenicity, and protects transgenic plants from infection. Physiol. Mol. Plant Pathol. 67: 108-115. http://dx.doi.org/10.1016/j.pmpp.2005.10.002

Maxwell JJ, Brick MA, Byrne PF, Schwartz HF, et al. (2007). Quantitative trait loci linked to white mold resistance in common bean. Crop Sci. 47: 2285-2294. http://dx.doi.org/10.2135/cropsci2007.01.0022

Miklas PN (2007). Marker-assisted backcrossing QTL for partial resistance to Sclerotinia white mold in dry bean. Crop Sci. 47: 935-942. http://dx.doi.org/10.2135/cropsci2006.08.0525

Miklas PN, Kelly JD, Beebe SE and Blair MW (2006). Common bean breeding for resistance against biotic and abiotic stresses: from classical to MAS breeding. Euphytica 147: 105-131. http://dx.doi.org/10.1007/s10681-006-4600-5

Mkwaila W, Terpstra KA, Ender M and Kelly JD (2011). Identification of QTL for agronomic traits and resistance to white mold in wild and landrace germplasm of common bean. Plant Breed. 130: 665-672. http://dx.doi.org/10.1111/j.14390523.2011.01876.x

Myers JR, Gilmore BS and Haggard JE (2008). Progress in characterization and transfer of white mold resistance from runner to common bean. Annu. Rep. Bean Improv. Coop. 51: 80-81.

Oliveira MB, Nascimento LB, Junior ML and Petrofeza S (2010). Characterization of the dry bean polygalacturonaseinhibiting protein (PGIP) gene family during Sclerotinia sclerotiorum (Sclerotiniaceae) infection. Genet. Mol. Res. 9: 994-1004. http://dx.doi.org/10.4238/vol9-2gmr776

Pfaffl MW (2001). A new mathematical model for relative quantification in real-time RT-PCR. Nucleic Acids Res. 29: e45. http://dx.doi.org/10.1093/nar/29.9.e45

Powell ALT, van Kan J, ten Have A, Visser J, et al. (2000). Transgenic expression of pear PGIP in tomato limits fungal colonization. Mol. Plant Microbe Interact. 13: 942-950. http://dx.doi.org/10.1094/MPMI.2000.13.9.942

Ridley BL, O’Neill MA and Mohnen D (2001). Pectins: structure, biosynthesis, and oligogalacturonide-related signaling. Phytochemistry 57: 929-967. http://dx.doi.org/10.1016/S0031-9422(01)00113-3

Schwartz HF and Singh SP (2013). Breeding common bean for resistance to white mold: a review. Crop Sci. 53: $1832-$ 1844. http://dx.doi.org/10.2135/cropsci2013.02.0081

Silva PH, Santos JB, Lima IA, Lara LA, et al. (2014). Reaction of common bean lines and aggressiveness of Sclerotinia sclerotiorum isolates. Genet. Mol. Res. 13: 9138-9151. http://dx.doi.org/10.4238/2014.November.7.11

Singh SP, Terán H, Schwartz HF, Otto K, et al. (2009). White mold-resistant interspecific common bean germplasm lines VCW 54 and VCW 55. J. Plant Regist. 3: 191-197. http://dx.doi.org/10.3198/jpr2008.11.0650crg

Soule M, Porter L, Medina J, Santana GP, et al. (2011). Comparative QTL map for white mold resistance in common bean, and characterization of partial resistance in dry bean lines VA19 and 19365-3. Crop Sci. 51: 123-139. http://dx.doi. org/10.2135/cropsci2010.06.0356

Terán H, Lema M, Schwartz HF, Duncan R, et al. (2006). Modified Petzoldt and Dickson scale for white mold rating of common bean. Annu. Rep. Bean Improv. Coop. 49: 115-116.

Viteri DM, Otto K, Terán H, Schwartz HF, et al. (2015). Use of four Sclerotinia sclerotiorum isolates of different aggressiveness, three inoculations per plant, and delayed multiple evaluations to select common beans with high levels of white mold resistance. Euphytica 204: 457-472. http://dx.doi.org/10.1007/s10681-015-1366-7

Genetics and Molecular Research 15 (3): gmr.15038269 